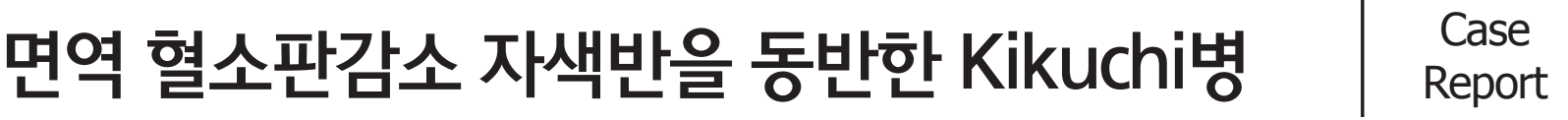 1예
}

김원용, 이승범, 최준정 ${ }^{1}$, 강희철*

연세대학교 의과대학 가정의학교실, ${ }^{1}$ 연세대학교 세브란스병원 진단병리과

\section{A Case Report of Kikuchi-Fujimoto Disease with Immune Thrombo- cytopenic Purpura}

Won-Yong Kim, Seung-Beom Lee, Jun-Jeong Choi ${ }^{1}$, Hee-Cheol Kang*
Department of Family Medicine, Yonsei University College of Medicine, ${ }^{1}$ Department of Pathology, Severance Hospital, Seoul, Korea

Kikuchi-Fujimoto disease (histiocytic necrotizing lymphadenitis) is a rare disease characterized by lymphadenitis with fever. It is self-limited within one to four months, and is generally diagnosed by an excisional biopsy of the affected lymph node. Kikuchi-Fujimoto disease has a wide variety of nonspecific symptoms and it is sometimes misdiagnosed as malignant lymphoma, lymph node tuberculosis, or systemic lupus erythematosus. Because clinical course and treatment of this disease differ from those of others, Kikuchi-Fujimoto disease must be included in differential diagnosis of enlarged lymph node. In this report, we discribed a case of 24-year-old male patient who visited the clinic complaining of fever, petechiae, and enlarged lymph node. He was diagnosed as Kikuchi-Fujimoto disease and immune thrombocytopenic purpura.

Keywords: Kikuchi-Fujimoto Disease; Histiocytic Necrotizing Lymphadenitis; Immune Thrombocytopenic Purpura

서론

Kikuchi병(Kikuchi-Fujimoto disease, histiocytic necrotizing lymphadenitis)은 압통을 동반한 양성 림프절 비대와 발열을 특 징으로 하는 드문 질환이다. 주로 40세 미만의 젊은 여성에서 발생하는 것으로 알려져 왔으나, ${ }^{1,2}$ 최근의 보고에 따르면 여 성에서의 발병률이 과대 평가되어 남녀 성비는 거의 $1: 1$ 에 가 깝다고 한다. ${ }^{3,4)}$ 환자에 따라 야간 발한, 상기도 감염증상, 체중 감소, 피부 발진, 백혈구 감소증, 호중구 감소증, 범혈구 감소

Received: September 21, 2009, Accepted: November 22, 2009

${ }^{*}$ Corresponding Author: Hee-Cheol Kang

Tel: 02-2228-2331, Fax: 02-362-2473

E-mail: kanghc@yuhs.ac

Korean Journal of Family Medicine

Copyright ( 2010 by The Korean Academy of Family Medicine
증 등 다양한 임상 증상과 검사실 소견을 나타낸다. 진단으로 는 조직학적인 절제생검을 통해 중성구 침윤이 없는 괴사성 림프절염이 보이면 확진할수 있다.,5) 발병원인으로는 바이러 스 감염이나 자가 면역 질환과의 관련성 등이 보고되고 있으 나 아직 확실히 밝혀진 것은 없다. 국내에서도 전신홍반루프 스와 동반된 경우와 더불어 여러 증례들이 보고된 바 있으나, 백혈구 감소증이나 적혈구 감소증 없이 혈소판 감소증 만을 동반한 경우는 없었다. 세계적으로는 백혈구 감소와 혈소판 감소가 같이 동반된 경우의 보고가 있었으며, ${ }^{6)}$ 면역 혈소판감 소자색반(특발 혈소판감소 자반병, immune thrombocytopenic purpura, idiopathic thrombocytic purpura, ITP)을 동반한 경우 에 대해 1 예의 보고가 있었다.7) 저자들은 발열과 구내 궤양, 전 신의 출혈점, 경부 림프절 비대를 주소로 내원한 환자에서 면 역 혈소판감소 자색반을 진단하고 림프절 조직 생검을 통해 Kikuchi병을 확진한 증례를 경험하였기에 문헌 고찰과 함께 보고하고자 한다. 
증례

24세 남자 환자가 3 주 전부터의 발열, 우측 목의 종괴, 인후 통을 주소로 외래를 내원하여 1 주간 비스테로이드항염증제 와 항생제로 치료받은 후 증세가 약간 호전되는 듯 하였으나, 다수의 쉽게 출혈을 일으키는 구내의 궤양, 전신의 출혈점이 생기고 발열이 심해져 가정의학과로 입원하였다. 결핵이나 만성질환, 자가면역 질환의 과거력은 없었으며 6년 전부터 알 레르기 비염이 있었지만 증세가 심하지 않아 별다른 치료는 하지 않았다고 한다.

내원 당시 환자는 급성 병색을 보였으며, 생체 징후는 혈 압 $110 / 80 \mathrm{mmHg}$, 맥박 80 회/분, 체온 $38.8^{\circ} \mathrm{C}$, 호흡수 20 회/분 이였고, 다발성 구강 궤양과, 전신의 출혈점, 우측 경부의 림프 절 비대가 관찰 되였다. 공막에 황달은 없었으며 결막은 창백 하지 않았다. 호흡음과 심음의 이상소견은 없었으며, 경부 이 외에 촉지되는 림프절은 없었다.

내원 당일 시행한 흥부 $X$ 선 촬영 검사상 특이 소견은 없었 으며, 경부 초음파 검사에서 우측 경부의 다발성 림프절 비대 가 관찰되었고 크기는 0.9-2.1 cm으로 다양하였다. 복부골반 전산단층촬영상 $14 \mathrm{~cm}$ 크기의 경도의 비장비대 이외에 다른 이상 소견은 없었다.

입원 당시 시행한 말초혈액검사에서는 혈색소 $14.3 \mathrm{~g} /$ $\mathrm{dL}$, 백혈구 5,770/ $\mu \mathrm{L}$ (호중구 46.5\%), 혈소판 6,000/ $\mu \mathrm{L}, \mathrm{ESR}$ $15 \mathrm{~mm} / \mathrm{hr}$ 이었다. 혈액 응고 검사상 프로트롬빈 시간은 international normalized ratio (INR) 1.12로 약간 증가된 양상이
었고 활성화부분트롬보플라스틴 시간은 정상이었다. 혈청 생화학 검사 소견은 AST $50 \mathrm{IU} / \mathrm{L}, \mathrm{ALT} 44 \mathrm{IU} / \mathrm{L}, \mathrm{GGT} 22 \mathrm{IU} /$ $\mathrm{L}, \mathrm{LDH} 842 \mathrm{IU} / \mathrm{L}$, 총 빌리루빈 $0.4 \mathrm{mg} / \mathrm{dL}, \mathrm{BUN} 14.5 \mathrm{mg} / \mathrm{dL}$, Creatinine $1.0 \mathrm{mg} / \mathrm{dL}$ 이었다. 요 검사상 이상소견은 없었다. 면 역혈청검사에서 C-반응단백 $2.3 \mathrm{mg} / \mathrm{dL}$ 이었다. 입원 후 Kikuchi 병 확진 시까지 14일간 항생제 ceftriaxone, roxithromycin으로 치 료하였고, 입원 당시 혈소판은 $6,000 / \mu \mathrm{L}$ 로 심한 혈소판 감소 증 소견을 보여 농축 혈소판 8 단위를 수혈하였다. 수혈 후 측 정된 혈소판은 $7,000 / \mu \mathrm{L}$ 로 심한 혈소판 불응증을 보였다. 면 역 혈소판감소 자색반이나 혈전성 혈소판감소 자색반등의 혈 소판 수혈의 상대적 금기증으로 생각되어 이후에 혈소판 수 혈은시행하지 않았다.

입원 이후 시행한 류마티스인자, 항핵항체, 항DNA항 체 검사는 모두 음성이었다. 한랭응집소 검사는 음성이었 고, 혈소판관련 IgG (platelet-associated immunoglobulin) 양 성, 항 혈소판 항체는 음성이었다. 바이러스 항체 검사에서 $\mathrm{HBsAg}$ 양성이었고, A형 간염 바이러스, C형 간염바이러스, cytomegalovirus (CMV), epstein-barr Virus (EBV), 톡소포자충, 사람면역결핍바이러스, 대상포진바이러스에 대한 항체는 모 두음성이었다. 혈액 배양검사와 객담 배양 검사, 뇨 배양 검사 에서 특이 소견은 없었다.

입원 3일째부터 입안의 궤양은 호전되는 양상을 보였으며 전신의 출혈점도 호전되었다. 혈소판수치는 꾸준히 증가하여 입원 7일째에는 $54,000 / \mu \mathrm{L}$ 이었고, 퇴원 시까지 계속 증가하였 다. 입원 7일째 골수 흡인 검사를 시행하였으나 골수성 원인 의 혈소판 감소증이나 혈액 종양을 시사하는 소견은 없었다.
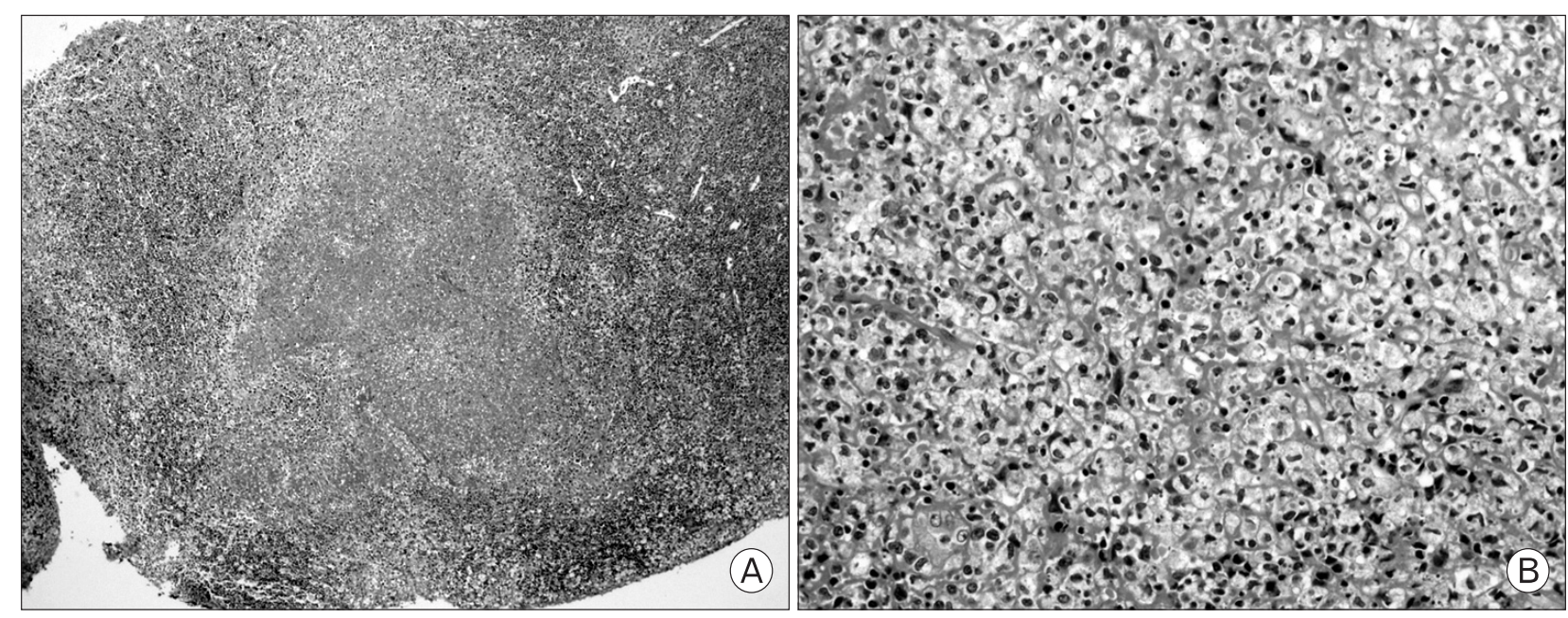

Figure 1. Lymph node biopsy shows diffused necrosis with karyorrhectic nuclear fragments, histeocytes, large lymphoid cells and macrophages $(H \& E,[A] \times 40,[B] \times 200)$. 
입원 10 일째 우측 경부 후삼각 부위의 림프조직에 절제생검 을 시행하였다. 입원 11 일째 발열이 소실되었고, 입원 14 일째 입원 첫날 혈소판 수혈 이후 특별한 치료없이 혈소판 수치가 $146,000 / \mu \mathrm{L}$ 까지 증가되었다. 14 일째 보고된 조직 병리 검사 결과상 림프절 조직의 여러 부위에 괴사 부분이 산재되고 괴 사 부위에 핵붕괴 물질과 단핵구 침윤이 보이는 아급성 괴사 성 림프절염에 합당한 소견을 보여 Kikuchi병으로 진단하였다 (Figure 1). 루푸스에서 발생하는 림프절염의 특징적인 형질세 포나 중성구 침윤은 관찰되지 않았으며, Zheil-Neelsen염색에 서 결핵균은 발견되지 않았다. 전신상태 양호해져서 입원 15 일째 퇴원하여 현재 외래 추적관찰 중이다.

\section{고찰}

아급성 괴사성 림프절염으로도 알려져 있는 Kikuchi병은 1972년 거의 동시에 Kikuchi와 Fujimoto에 의해 최초로 보고된 병이다. Kikuchi병에서의 림프절 비대는 많은 경우에서 경부 림프절을 침범하며 이중에서도 경부 후삼각의 단일 림프절을 침범하는 경우가 가장 많다. ${ }^{24)}$ 다른 증상은 환자에 따라 다양 하게 나타나 림프절 비대와 발열 이외에 가벼운 상기도 증세 나, 구역, 구토, 인후통, 체중감소 야간 발한 등이 보고되고 있 으며, ${ }^{2,4}$ 흔하지는 않지만 주로 안면부와 상반신을 침범하는 비특이적인 여러 종류의 피부발진, ${ }^{8,9}$ 구강 궤양, 구순염이 같 이 발생한다고 한다. ${ }^{10,11)}$

검사실 소견도 다양하여 정상인 경우도 많으며, 가장 흔 한 소견으로는 가벼운 백혈구 감소증이 $25-58 \%$ 정도에서 관 찰되며 과립구 감소증도 $25-31 \%$ 정도에서 보인다. ${ }^{12)}$ 아주 드 물게 혈구 탐식증(hemophagocytic syndrome)과 병발하는 경 우 빈혈과 심한 혈소판 감소증을 동반한다고 보고되고 있으 며, 예후도 좋지 않은 것으로 알려져 있다. ${ }^{13,14)}$ 혈구 탐식증은 7 일 이상의 불명열과 더불어 설명되지 않는 2 개 이상의 세포주 (cell line)를 침범하는 혈구 감소증을 보이며, 파종혈관내 응고, 간기능 이상을 나타내면서 골수검사상 골수내 혈구 탐식성 조직구가 $3 \%$ 이상인 소견을 포함하는 병으로 치사율이 $42 \%$ 에 이른다. ${ }^{13)}$

Kikuchi병의 병인은 아직 확실히 밝혀지지 않은 상태로 바 이러스 감염이나 자가면역 질환과의 관련성이 제시되고 있 다. 면역조직소견상 바이러스 감염 질환과 유사한 소견을 보 이고, Kikuchi병의 진행에 따른 $\alpha$-인터페론 변화 양상이 바이 러스 감염과 비슷하다는 점에서 바이러스 질환과의 연관성에 대한 설이 제기되고 있으나 병변에서 바이러스 동정은 이루
어지지 못했고 특정 원인 바이러스를 밝히지는 못한 실정이 다. ${ }^{15)}$ 전신홍반루푸스, 다발성 근육염, 혼합 결체조직 질환, 항 인지질 증후군, 성인형 스틸병과의 연관성이 보고된 바 있고, 루프스 환자의 내피세포에서 세관망상형 구조 소견과 Kikuchi 병 환자의 조직구나 림프구, 내피세포에서 보이는 소견이 유 사함을 들어 자가 면역질환과의 연관성을 주장하는 학자도 있으나아직 근거가 부족하다. ${ }^{16)}$

이 증례는 압통이 동반된 림프절 종대와 발열로 외래 치료 중이던 환자가 심한 혈소판 감소증이 동반되며 전신의 점상 출혈과 구내 출혈성 궤양이 생겨 입원하게 된 경우이다. 바이 러스 감염증에 의한 림프절 염을 감별하기 위하여 시행한 항 체검사는 모두 음성이었으며 $\mathrm{EBV}$ 는 과거의 감염으로 나타나 배제할 수 있었다. 루푸스나 다른 자가 면역 질환을 감별하기 위해 실시한 류마티스인자, 항핵항체, 항DNA항체는 모두 음 성이었고 한랭응집소 검사도 음성이었다. 확진적이지는 않지 만 면역 혈소판감소 자색반일 때 증가하는 혈소판관련 $\mathrm{IgG}$ 의 상승을 보였다. ${ }^{17}$

경부 림프절 세균 감염 시 가장 흔한 원인이 되는 균은 포 도알구균과 사슬알균이다. 드문 원인이 되는 균은 Bartonella, atypical mycobacterium, 결핵균 등이 있다. 이에 따라 배양검사 결과가 나오지 않았을 때 사용할 수 있는 경험적 경구 항생제 는 cephalexin, amoxicillin/clavulanate, clindamycin의 10 일 사용 이 권고 되고 있다. ${ }^{18)}$ 본 증례에서는 외래 진료 시 amoxicillin/ clavulanate을 사용하였으며 내성균에 의한 감염이 의심되어 ceftriaxone, roxithromycin을 Kikuchi병 확진 시까지 사용하였다.

저자들은 3 주간의 상기도 증세 이후에 발생한 것, 혈소판 관련 $\mathrm{IgG}$ 의 상승과 극심한 말초성 혈소판감소, 혈소판 수혈에 대한 불응증, 별다른 치료 없이 호전된 점, 다른 면역학적 질환 이나 악성 질환의 증거가 없는 점 등을 볼 때 면역 혈소판감소 자색반을 진단할 수 있었다. 혈소판 감소 자색반은 감염이나 전신질환에 의한 자가 항체나 면역복합체가 생기는 면역반응 과의 연관성이 잘 알려져 있는 질환으로 ${ }^{17)}$ 이 증례는 Kikuchi 병이 면역반응의 일종으로 생각하는 기존의 학설을 뒷받침하 는 증거의 하나로 생각할 수 있다.

Kikuchi병에서 특징적인 초음파 검사나 컴퓨터 단층 촬영 검사, 자기공명 영상 소견은 없으며, 때로는 이들 소견이 악성 림프종이나, 전이성암, 결핵종과 혼동되기도 한다.) 진단적인 검사는 림프절 절제생검이다. 44 증례를 분석한 Tong 등 ${ }^{19}$ 에 따르면 세침 흡인 검사의 진단적 정확성은 $56.3 \%$ 로 낮았으나, 최근에 Kim 등 ${ }^{20)}$ 은 초음파 유도 중심부 바늘 생검이 민감도 $97.9 \%$, 특이도 $99.1 \%$ 를 나타내어 안전하고 효과적으로 사용될 수 있다고 보고하였다. 림프절 조직에서 속겉질과 겉질에서 
불규칙하게 분포하는 호산성의 괴사 영역, 괴사 영역에서 두 드러지게 나타나는 불규칙하게 분포하는 핵파편들, 중성구가 없으며 형질세포가 아주 드물게 나타나는 것, 형질 세포양 $\mathrm{T}$ 림프구 혹은 단핵구들의 집락화, 그리고 수많은 면역 모세포 의 출현 등이 나타날 때 진단할 수 있다. ${ }^{12)}$

Kikuchi병이 비교적 드문 질환이긴 하지만 우리나라와 일 본을 비롯한 동아시아 지역에서는 서구에 비해 호발하는 병 이며 림프절 비대를 주소로 하는 악성 림프종, 림프절 결핵, 전 신홍반루푸스에 의한 림프절 비대 등과는 예후와 치료가 완 전히 다르므로 감별 진단 시 반드시 고려할 필요가 있다. 이외 의 감별질환으로는 야토병, 묘소증, 예르시니아 감염증, 톡소 포자충 림프절염, 후천성 면역 결핍증 바이러스 감염에 의한 림프절염, 전염성 단핵구증, 림프절 경색, 가와사끼병 등이 있 다. ${ }^{5,16)}$

병의 경과는 대부분 4 개월 이내에 자연 치유되며, 대부분 진단 이전에 항생제를 사용하게 되지만 병의 경과나 예후에 는 영향을 끼치지 않는다. 재발률은 3-4\%이며, 대증적으로 비 스테로이드성 항염제를 사용하며 전신홍반루푸스와 동반되 어 있는 경우 스테로이드 사용이 병의 진행 경과를 줄인다는 보고 ${ }^{21)}$ 가 있으나 증례가 세 경우에 불과해 좀 더 연구가 필요 할 것으로 생각된다.

\section{요약}

Kikuchi병은 발열을 동반한 림프절 비대를 주 증상으로 하는 드문 질환으로 자연치유 되는 특징을 가지고 있으며 림프절 의 조직학적 절제생검을 통하여 진단된다. 흔한 질환은 아니 지만 질병의 양상이 매우 다양하고 증상이 비특이적으로 악 성 림프종, 결핵, 또는 전신홍반성루푸스로 오진되는 경우도 종종 있으므로 림프절 비대를 나타내는 환자에서 다른 질환 의 소견이 뚜렷하지 않다면 감별 진단 시 Kikuchi병에 대한 고 려가 필요하다. 저자들은 발열, 전신 출혈점, 경부 림프절 비대 를 주소로 내원하여 면역 혈소판감소 자색반과 Kikuchi병을 진단받은 환자 1 예를 경험하였기에 문헌고찰과 함께 증례를 보고하는 바이다.

중심단어: Kikuchi 병; 괴사성 아급성 림프절염; 면역 혈소판 감소자색반

\section{REFERENCES}

1. Kikuchi M. Lymphadenitis showing focal reticulum cell hyperplasia with nuclear debris and phagocytosis. Acta Hematol Jpn 1972;35:379-80.

2. Dorfman RF, Berry GJ. Kikuchi's histiocytic necrotizing lymphadenitis: an analysis of 108 cases with emphasis on differential diagnosis. Semin Diagn Pathol 1988;5:329-45.

3. Lin HC, Su CY, Huang CC, Hwang CF, Chien CY. Kikuchi's disease: a review and analysis of 61 cases. Otolaryngol Head Neck Surg 2003;128:650-3.

4. Kuo TT. Kikuchi's disease (histiocytic necrotizing lymphadenitis). A clinicopathologic study of 79 cases with an analysis of histologic subtypes, immunohistology, and DNA ploidy. Am J Surg Pathol 1995; 19:798-809.

5. Bosch X, Guilabert A, Miquel R, Campo E. Enigmatic KikuchiFujimoto disease: a comprehensive review. Am J Clin Pathol 2004;122:141-52.

6. Eboriadou M, Tragiannidis A, Markou K, Athanassiadou F. Kikuchi-fujimoto disease associated with extreme leukopenia and thrombocytopenia in an adolescent boy. J Pediatr Hematol Oncol 2007;29:864.

7. Jun-Fen F, Chun-Lin W, Li L, Dayan C, Guan-Ping D, Fang H. Kikuchi-Fujimoto disease manifesting as recurrent thrombocytopenia and Mobitz type II atrioventricular block in a 7-year-old girl: a case report and analysis of 138 Chinese childhood Kikuchi-Fujimoto cases with 10 years of follow-up in 97 patients. Acta Paediatr 2007;96:1844-7.

8. Atwater AR, Longley BJ, Aughenbaugh WD. Kikuchi's disease: case report and systematic review of cutaneous and histopathologic presentations. J Am Acad Dermatol 2008;59:130-6.

9. Yasukawa K, Matsumura T, Sato-Matsumura KC, Takahashi T, Fujioka Y, Kobayashi H, et al. Kikuchi's disease and the skin: case report and review of the literature. Br J Dermatol 2001;144:8859.

10. Imai K, Yokozeki H, Nishioka K. Kikuchi's disease (histiocytic necrotizing lymphadenitis) with cutaneous involvement. J Dermatol 2002;29:587-92.

11. Yen A, Fearneyhough P, Raimer SS, Hudnall SD. EBV-associated Kikuchi's histiocytic necrotizing lymphadenitis with cutaneous 
manifestations. J Am Acad Dermatol 1997;36(2 Pt 2):342-6.

12. Choi JW, Lee JH, Lee JH, Chae YS, Kim I. The clinicopathologic analysis of Kikuchi's lymphadenitis. Korean J Pathol 2004;38: 289-94.

13. Kim YM, Lee YJ, Nam SO, Park SE, Kim JY, Lee EY. Hemophagocytic syndrome associated with Kikuchi's disease.J Korean Med Sci 2003;18:592-4.

14. Mahadeva U, Allport T, Bain B, Chan WK. Haemophagocytic syndrome and histiocytic necrotising lymphadenitis (Kikuchi's disease). J Clin Pathol 2000;53:636-8.

15. Cho JK, Han SJ, Bae JY, Chung SH, Kim CG, Choe JY. A case of recurrent Kikuchi-Fujimoto disease with SLE. Korean J Med 2006;70:107-10.

16. Ahn CY, Oh MG, Ha JH, Kim SH, Hur JA. A case of systemic lupus erythematosus associated with Kikuchi-Fujimoto's disease. J Korean Rheum Assoc 2007; 14:297-301.
17. Shin HY. Immune thrombocytopenic purpura (ITP). Korean J Pediatr 2006;49:830-2.

18. Dulin MF, Kennard TP, Leach L, Williams R. Management of cervical lymphadenitis in children. Am Fam Physician 2008;78:1097-8.

19. Tong TR, Chan OW, Lee KC. Diagnosing Kikuchi disease on fine needle aspiration biopsy: a retrospective study of 44 cases diagnosed by cytology and 8 by histopathology. Acta Cytol 2001;45:953-7.

20. Kim BM, Kim EK, Kim MJ, Yang WI, Park CS, Park SI Sonographically guided core needle biopsy of cervical lymphadenopathy in patients without known malignancy.J Ultrasound Med 2007;26:585-91.

21. Jang YJ, Park KH, Seok HJ. Management of Kikuchi's disease using glucocorticoid. J Laryngol Otol 2000;114:709-11. 